DOI: $10.6060 / \mathrm{mhc} 1708321$

\title{
A Study of the Reaction between Methylpyropheophorbide $a$ and Hydrazine Hydrate
}

\author{
Ivan S. Lonin, ${ }^{a} @$ Evgeny S. Belyaev, ${ }^{a}$ Aslan Yu. Tsivadze, ${ }^{a}$ Gelii V. Ponomarev, ${ }^{\text {b }}$ \\ Natalya N. Lonina, ${ }^{\mathrm{c}}$ Andrew N. Fitch, ${ }^{\mathrm{d}}$ and Vladimir V. Chernyshev ${ }^{\mathrm{a}, \mathrm{e}}$ \\ Dedicated to Academician of Russian Academy of Sciences Aslan Yu. Tsivadze \\ on the occasion of his Birthday
}

\author{
${ }^{a}$ A.N. Frumkin Institute of Physical Chemistry and Electrochemistry of Russian Academy of Sciences, 119071 Moscow, Russia \\ ${ }^{\mathrm{b}}$ Research Institute of Biomedical Chemistry, 119121 Moscow, Russia \\ ${ }^{c}$ Moscow Technological University, Institute of Fine Chemical Technologies, 119571 Moscow, Russia \\ ${ }^{\mathrm{d}}$ European Synchrotron Radiation Facility, B. P. 220, 38043 Grenoble Cedex, France \\ ${ }^{\mathrm{e}}$ Chemical Department, Moscow State University, 119991 Moscow, Russia \\ ${ }^{\circledR}$ Corresponding authorE-mail: loninis@gmail.com
}

\begin{abstract}
The reaction between pyropheophorbide a methyl ester (1) and hydrazine hydrate has been studied. It was shown that the reagents ratio governs the particular reaction product formation. Treatment of 1 by excess of hydrazine hydrate (more than 3 eq.) yielded methylmesopyropheophorbide a hydrazone (2) as a major product. On the other hand, only methylmesopyropheophorbide a azine (4) was formed when the equimolar amounts of the reagents were applied. In order to prevent the C3-vinyl group reduction in 1 by hydrazine hydrate, the reaction was carried out in the presence of trifluoroacetic acid (TFA). It was shown, that the selectivity of the reaction is regulated by the hydrazine hydratel TFA ratio. Thus, the optimal conditions for the selective synthesis of both methylpyropheophorbide a hydrazone (3) and azine (5) have been found. The formation of the dimeric structure of azines was determined by the X-ray powder diffraction.
\end{abstract}

Keywords: Chlorophyll, hydrazones, azines, photosensitizer, pyropheophorbide $a$, dimer, solar energy, natural chlorins, NMR, PDT, X-ray, powder diffraction.

\section{Изучение реакции метилпирофеофорбида $a$ с гидразингидратом}

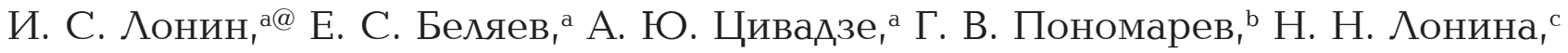 \\ А. Н. Фитч, ${ }^{d}$ B. В. Чернышев ${ }^{a, e}$
}

${ }^{a}$ Институт физической химии и электрохимии имени А.Н. Фрумкина Российской академии наук, 119071 Москва, Россия

${ }^{\mathrm{b}}$ Научно-исследовательский институт биомедицинской химии имени В.Н. Ореховича, 119121 Москва, Россия

'Московский технический университет, Институт тонких химических технологий, 119571 Москва, Россия

${ }^{\mathrm{d}}$ Европейский изентр синхротронного излучения, В. Р. 220, 3804,3 Гренобль, Франциия

'Московский государственный университет имени М.В. Ломоносова, Химический факультет 119991 Москва, Россия

@E-mail: loninis@gmail.com

Изучена реакция метилпирофеофорбида а (1) с гидразингидратом. Показано, как соотношение реагентов влияет на образование продуктов реакции. В присутствии избытка гидразингидрата (более 3 экв.) преимущественно образуется соответствуюший гидразон метилмезопирофеофорбида а (2), тогда как при взаимодействии эквимолярных количеств реагентов единственным продуктом реакции является азин метилмезопирофеофорбида а (4). Для предотвращения восстановления С3-винильной группь хлоринового макроцикла 
при взаимодействии 1 с гидразингидратом, реакцию осуществляли в присутствии трифторуксусной кислоты (ТФК). Показано, что селективность реакции регулируется соотношением гидразингидрат/ТФК, что позволило подобрать оптимальные условия для направленного синтеза как гидразона метилпирофеофорбида а (3), так и азина (5). Образование димерной структуры азинов было установлено методом порошкового РСА.

Ключевые слова: Хлорофилл, гидразоны, фотосенсибилизаторы, пирофеофорбид $a$, димер, солнечная энергия, природные хлорины, ЯМР, ФДТ, порошковая дифракция, РСА.

\section{Introduction}

Due to the unique photophysical and electrochemical properties natural chlorins are being intensively studied as photosensitizes (PSs) for diverse fields of science and technology, including solar cells, photodynamic therapy (PDT) agents, chemical sensors etc. ${ }^{[1-3]}$ In nature these molecules are present in chloroplasts as a part of the antenna complex, functioning as a light harvesting and energy transferring devise. Back engineering of the natural photosystems may lead to the creation of the photoactive materials for solar energy conversion. ${ }^{[4-6]}$ A fine tuning of the chlorophylls optical properties is essential for the efficient energy-harvesting, energy-migrating, and charge-separating processes at the initial stages of natural photosynthesis. The same is also applied for the synthetically derived chlorins acting as photoactive materials in solar cells..$^{[7,8]}$

The electronic absorption spectra of the natural chlorins are dependent on the peripheral substituents. The most prominent characteristic of which is the longest wavelength $\left(Q_{y}\right)$ band. The position and intensity of the redmost $Q_{y}$ maximum is related to the molecular transition dipole moment along the $y$-axis, which in turn affected by the $\pi$-conjugated functional groups located in the C3- and C13-positions of the macrocycle. ${ }^{\left[{ }^{19-11]}\right.}$ A number of synthetic approaches has been reported for the $C 3$-substituents modification, involving different methodologies such as condensation and olefination reactions, Pd-catalyzed cross-couplings, 1,3-cycloaddition etc. ${ }^{[12-14]}$ Chemical modification of the 13-carbonyl group has been also reported. ${ }^{[15-18]}$

Previously we described an efficient approach towards the 3-vinyl group substitution involving cross-coupling reactions. ${ }^{[19]}$ In continuation of our research for synthesis of the naturally derived chlorins with the enhanced optical properties we focused on the modification of the 13-carboxy group of the chlorophyll $a$ derivatives.

\section{Experimental}

The solvents were purified and prepared using standard procedures. All reactions were carried out with protection from direct light. Pyropheophorbide $a$ methyl ester (1) was obtained using a known procedure. ${ }^{[20]}$ Column chromatography was carried out on 40/60 silica gel (Merck). Preparative TLC was performed on silica gel 60 (Merck) using $20 \times 20 \mathrm{~cm}$ plates with a layer thickness of $1 \mathrm{~mm}$. Analytical TLC was carried out on Kieselgel 60 F245 plates (Merck). Electronic spectra were recorded using a HITACHI U-2900 spectrophotometer. NMR spectra were recorded at $25^{\circ} \mathrm{C}$ on Bruker Avance III 600 spectrometer. The signals of carbon atoms and those of residual protons of $\mathrm{CDCl}_{3}$ were used to calibrate the ${ }^{13} \mathrm{C}$ and ${ }^{1} \mathrm{H}$ scales, respectively. ${ }^{[21]}$ All NMR experiments were based on standard Bruker techniques. The evolution delay in ${ }^{1} \mathrm{H}-{ }^{13} \mathrm{C}$ gHMBC experiment was $60 \mathrm{~ms}$. Mass spectra were obtained on a Ultraflex II Bruker Daltonics time-of-flight mass spectrometer using the SALDI method.

$X$-Ray powder diffraction measurements were carried out at $250 \mathrm{~K}$ at beam line ID22 of the European Synchrotron Radiation Facility (ESRF, Grenoble, France). The instrument is equipped with a cryogenically-cooled, double-crystal Si 111 monochromator and Si 111 analyzers. The powder was loaded into a 1-mm-diameter borosilicate thin-walled glass capillary which was rotated during measurements at a rate of $1200 \mathrm{rpm}$ to improve the powder averaging. Calibration of the instrument and refinement of the X-ray wavelength $(0.399996(3) \AA)$ were performed via NIST silicon standard 640c (see Table 1 for data collection details).

Indexing. Unit-cell dimensions were determined using three indexing programs: TREOR90, ${ }^{[22]}$ ITO $^{[23]}$ and AUTOX. ${ }^{[24,25]}$ Space group $C 2$ was assigned taking into account the systematic extinctions. The unit-cell parameters and space group were tested further with the use of the Pawley fit ${ }^{[26]}$ and confirmed by crystal structure solution.

Structure Determination. The crystal structure was solved with the use of simulated annealing technique ${ }^{[27]}$ and program MRIA. ${ }^{[28]}$ The model of the molecule used in a direct space search without $\mathrm{C}$-bound $\mathrm{H}$ atoms was optimized by density functional theory (DFT) calculations in vacuo using the quantum-chemical program PRIRODA, ${ }^{[29-32]}$ employing the generalized gradient approximation (GGA) and the PBE exchange-correlation function (Perdew et al., 1996). ${ }^{[33]}$ Taking into account the unit cell volume and space group symmetry an obvious conclusion was made that only two molecules can be situated in the unit cell, i.e. $\mathrm{Z}=2$. This condition can be satisfied only if the molecule is situated on a twofold axis. Therefore, one-half molecule has been used in a direct space search for the crystal structure solution.

\section{Synthesis}

Methylmesopyropheophorbide a hydrazone (2). To a solution of $100 \mathrm{mg}(0.182 \mathrm{mmol})$ of methylpyropheophorbide $a$ in $30 \mathrm{~mL}$ of $\mathrm{CH}_{2} \mathrm{Cl}_{2}$ hydrazine hydrate $(90.1 \mu \mathrm{L}, 1.820 \mathrm{mmol})$ was added. The reaction was heated at $40{ }^{\circ} \mathrm{C}$ and the progress was monitored by TLC. Upon completion (3 days) the crude mixture was concentrated in vacuo and purified by column flash-chromatography $\left(\mathrm{CH}_{2} \mathrm{Cl}_{2} / \mathrm{EtOH}=100: 1\right)$. The product was crystallized from $\mathrm{CH}_{2} \mathrm{Cl}_{2} /$ hexane to afford $78 \mathrm{mg}$ of $\mathbf{2}$ ( $76 \%$ yield). $\mathrm{m} / \mathrm{z}$ (SALDI) found: 564.4 , 565.4, 566.4; calcd for $\mathrm{C}_{34} \mathrm{H}_{40} \mathrm{~N}_{6} \mathrm{O}_{2}: 564.32[\mathrm{M}]^{+}, \mathrm{C}_{33}{ }^{13} \mathrm{CH}_{40} \mathrm{~N}_{6} \mathrm{O}_{2}$ : $565.32[\mathrm{M}]^{+}, \mathrm{C}_{32}{ }^{13} \mathrm{C}_{2} \mathrm{H}_{40} \mathrm{~N}_{6} \mathrm{O}_{2}: 566.33[\mathrm{M}]^{+}$. UV-Vis $\left(\mathrm{CH}_{2} \mathrm{Cl}_{2}\right) \lambda_{\text {max }}$ $\left(\mathrm{A}_{\text {rel }}\right) \mathrm{nm}: 403$ (1.00), $504(0.18), 555(0.06), 608(0.10), 661(0.75)$. ${ }^{1} \mathrm{H}$ NMR $\left(\mathrm{CDCl}_{3}\right) \delta_{\mathrm{H}} \mathrm{ppm}: 9.65(1 \mathrm{H}, \mathrm{s}, 10-\mathrm{H}), 9.65(1 \mathrm{H}, \mathrm{s}, 5-\mathrm{H})$, $8.80(1 \mathrm{H}, \mathrm{s}, 20-\mathrm{H}), 5.44\left(1 \mathrm{H}, \mathrm{d} J=17.9 \mathrm{~Hz}, 13^{2}-\mathrm{CH}^{2 \mathrm{a}}\right), 5.30(1 \mathrm{H}$, d $\left.J=17.9 \mathrm{~Hz}, 13^{2}-\mathrm{CH}^{2 \mathrm{~b}}\right), 4.66(1 \mathrm{H}$, dq $J=7.4 \mathrm{~Hz}, J=1.7 \mathrm{~Hz}, 18-\mathrm{H})$, $4.48(1 \mathrm{H}, \mathrm{m}, 17-\mathrm{H}), 4.01\left(2 \mathrm{H}, \mathrm{q} J=7.8 \mathrm{~Hz}, 3^{1}-\mathrm{CH}_{2}\right), 3.85(2 \mathrm{H}, \mathrm{q}$ $\left.J=7.8 \mathrm{~Hz}, 8^{1}-\mathrm{CH}^{2}\right), 3.71\left(3 \mathrm{H}, \mathrm{s}, 12^{1}-\mathrm{CH}_{3}\right), 3.63\left(3 \mathrm{H}, \mathrm{s}, 17^{4}-\mathrm{CH}_{3}\right)$, 
$3.46\left(3 \mathrm{H}, \mathrm{s}, 2^{1}-\mathrm{CH}_{3}\right), 3.43\left(3 \mathrm{H}, \mathrm{s}, 7^{1}-\mathrm{CH}_{3}\right), 2.79\left(1 \mathrm{H}, \mathrm{m}, 1^{1}-\mathrm{CH}^{2 \mathrm{a}}\right)$, $2.63\left(1 \mathrm{H}, \mathrm{m}, 17^{2}-\mathrm{CH}^{2 \mathrm{a}}\right), 2.40\left(1 \mathrm{H}, \mathrm{m}, 17^{1}-\mathrm{CH}^{2 \mathrm{~b}}\right), 2.26\left(1 \mathrm{H}, \mathrm{m}, 17^{2}-\right.$ $\left.\mathrm{CH}^{2 \mathrm{~b}}\right), 1.88\left(3 \mathrm{H}, \mathrm{d} J=7.4 \mathrm{~Hz}, 18^{1}-\mathrm{CH}_{3}\right), 1.83\left(3 \mathrm{H}, \mathrm{t} J=7.8 \mathrm{~Hz}, 3^{2}-\right.$ $\left.\mathrm{CH}_{3}\right), 1.80\left(3 \mathrm{H}, \mathrm{t} J=7.8 \mathrm{~Hz}, 8^{2}-\mathrm{CH}_{3}\right), 0.16$ and $-2.83(2 \mathrm{H}$, each bs, $\mathrm{NH} \times 2) .{ }^{13} \mathrm{C} \mathrm{NMR}\left(\mathrm{CDCl}_{3}\right) \delta_{\mathrm{C}} \mathrm{ppm}: 173.8\left(\mathrm{C} 17^{3}\right), 168.1$ (C19), 160.7 (C16), 151.3 (C6), 150.7 (C13 $), 150.1$ (C9), 144.8 (C14), 143.6 (C8), 140.6 (C1), 139.9 (C11), 139.6 (C3), 135.7 (C7), 134.7 (C13), 133.7 (C4), 129.1 (C2), 124.5 (C12), 105.0 (C15), 100.9 (C10), 97.1 (C5), 92.4 (C20), 52.7 (C17), $51.6\left(\mathrm{C} 17^{4}\right), 49.6$ (C18), $37.2\left({\mathrm{C} 13^{2}}^{2}\right), 30.8\left(17^{2}\right), 29.5\left(\mathrm{C} 17^{1}\right), 23.7\left(\mathrm{C} 18^{1}\right), 19.7\left(\mathrm{C} 8^{1}\right), 19.6$ $\left(\mathrm{C} 3^{1}\right), 17.7\left(8^{2}\right), 17.3\left(\mathrm{C}^{2}\right), 12.2\left(\mathrm{C} 12^{1}\right), 11.5\left(\mathrm{C} 7^{1}\right), 11.1\left(\mathrm{C} 2^{1}\right)$.

Methylpyropheophorbide a hydrazone (3). To a solution of $100 \mathrm{mg}(0.182 \mathrm{mmol})$ of methylpyropheophorbide $a$ in $30 \mathrm{~mL}$ of $\mathrm{CH}_{2} \mathrm{Cl}_{2}$ hydrazine hydrate $(18 \mu \mathrm{L}, 0.364 \mathrm{mmol})$ and TFA (14 $\mu \mathrm{L}, 0.182 \mathrm{mmol})$ were added. The reaction was heated at $40{ }^{\circ} \mathrm{C}$ and the progress was monitored by TLC $(15 \mathrm{~h})$. The reaction mixture was poured to solution of $0.01 \mathrm{M} \mathrm{NaHCO}$ and extracted with $\mathrm{CH}_{2} \mathrm{Cl}_{2}$. The combined extracts were washed with water, dried over $\mathrm{Na}_{2} \mathrm{SO}_{4}$, and evaporated in vacuo to dryness. The residue was redisolved in $\mathrm{CH}_{2} \mathrm{Cl}_{2}$ and purified by preparative thin-layer chromatography in a $\mathrm{CH}_{2} \mathrm{Cl}_{2} / \mathrm{MeOH}$ system (100:1) to afford 3 (67 mg, 65 \%). $m / z$ (SALDI) found: 562.4, 563.5, 564.4; calcd for $\mathrm{C}_{34} \mathrm{H}_{38} \mathrm{~N}_{6} \mathrm{O}_{2}$ : $562.31[\mathrm{M}]^{+}, \mathrm{C}_{33}{ }^{13} \mathrm{CH}_{38} \mathrm{~N}_{6} \mathrm{O}_{2}: 563.31[\mathrm{M}]^{+}, \mathrm{C}_{32}{ }^{13} \mathrm{C}_{2} \mathrm{H}_{38} \mathrm{~N}_{6} \mathrm{O}_{2}: 564.31$ $[\mathrm{M}]^{+}$. UV-Vis $\left(\mathrm{CH}_{2} \mathrm{Cl}_{2}\right) \lambda_{\text {max }}\left(\mathrm{A}_{\text {rel }}\right) \mathrm{nm}: 407(1.00), 506(0.17), 534$ (0.04), 612 (0.06), $670(0.61) .{ }^{1} \mathrm{H} \mathrm{NMR}\left(\mathrm{CDCl}_{3}\right) \delta_{\mathrm{H}} \mathrm{ppm}: 9.74(1 \mathrm{H}$, s, $10-\mathrm{H}), 9.69(1 \mathrm{H}, \mathrm{s}, 5-\mathrm{H}), 8.81(1 \mathrm{H}, \mathrm{s}, 20-\mathrm{H}), 8.19(1 \mathrm{H}, \mathrm{dd} J=11.5$ $\left.\mathrm{Hz}, J=17.8 \mathrm{~Hz}, 3^{1}-\mathrm{H}\right), 6.36\left(1 \mathrm{H}, \mathrm{d} J=17.8 \mathrm{~Hz}, 3^{2}-\mathrm{H}^{\mathrm{a}}\right), 6.22(1 \mathrm{H}, \mathrm{d}$ $\left.J=11.5 \mathrm{~Hz}, 3^{2}-\mathrm{H}^{\mathrm{b}}\right), 5.58\left(1 \mathrm{H}, \mathrm{d} J=19.4 \mathrm{~Hz}, 13^{2}-\mathrm{CH}^{2 \mathrm{a}}\right), 5.49(1 \mathrm{H}, \mathrm{d}$ $\left.J=19.4 \mathrm{~Hz}, 13^{2}-\mathrm{CH}^{2 b}\right), 4.63(1 \mathrm{H}, \mathrm{dq} J=7.3 \mathrm{~Hz}, J=1.6 \mathrm{~Hz}, 18-\mathrm{H})$, $4.46(1 \mathrm{H}, \mathrm{m}, 17-\mathrm{H}), 3.85\left(2 \mathrm{H}, \mathrm{q} J=7.7 \mathrm{~Hz}, 8^{1}-\mathrm{CH}_{2}\right), 3.81(3 \mathrm{H}, \mathrm{s}$, $\left.12-\mathrm{CH}_{3}\right), 3.62\left(3 \mathrm{H}, \mathrm{s}, 17^{2}-\mathrm{CO}_{2} \mathrm{CH}_{3}\right), 3.54\left(3 \mathrm{H}, \mathrm{s}, 2-\mathrm{CH}_{3}\right), 3.39(3 \mathrm{H}$, s, 7- $\left.-\mathrm{CH}_{3}\right), 2.78\left(1 \mathrm{H}, \mathrm{m}, 17^{1}-\mathrm{CH}^{2 \mathrm{a}}\right), 2.58\left(1 \mathrm{H}, \mathrm{m}, 17^{2}-\mathrm{CH}^{2 \mathrm{a}}\right), 2.43$ $\left(1 \mathrm{H}, \mathrm{m}, 17^{1}-\mathrm{CH}^{2 \mathrm{~b}}\right), 2.25\left(1 \mathrm{H}, \mathrm{m}, 17^{2}-\mathrm{CH}^{2 \mathrm{~b}}\right), 1.85(3 \mathrm{H}, \mathrm{d} J=7.3 \mathrm{~Hz}$, $\left.18^{1}-\mathrm{CH}_{3}\right), 1.79\left(3 \mathrm{H}, \mathrm{t} J=7.7 \mathrm{~Hz}, 8^{2}-\mathrm{CH}_{3}\right), 0.11$ and $-2.61(2 \mathrm{H}$, each bs, $\mathrm{NH} \times 2$ ).

Methylmesopyropheophorbide a azine (4). To a solution of $100 \mathrm{mg}(0.182 \mathrm{mmol})$ of methylpyropheophorbide $a$ in 30 $\mathrm{mL}$ of $\mathrm{CH}_{2} \mathrm{Cl}_{2}$ hydrazine hydrate $(9 \mu \mathrm{L}, 0.182 \mathrm{mmol})$ was added. The reaction was heated at $40{ }^{\circ} \mathrm{C}$ and the progress was monitored by TLC. Upon completion (3 days) the crude mixture was concentrated in vacuo and purified by column flash-chromatography $\left(\mathrm{CH}_{2} \mathrm{Cl}_{2} / \mathrm{EtOH}=100: 1\right)$. The product was crystallized from $\mathrm{CH}_{2} \mathrm{Cl}_{2} /$ hexane to afford $90 \mathrm{mg}$ of 4 (90\% yield). $\mathrm{m} / \mathrm{z}$ (SALDI) found: 1097.6, 1098.6, 1099.6; calcd for $\mathrm{C}_{68} \mathrm{H}_{76} \mathrm{~N}_{10} \mathrm{O}_{4}: 1097.57[\mathrm{M}]^{+}$, $\mathrm{C}_{67}{ }^{13} \mathrm{CH}_{76} \mathrm{~N}_{10} \mathrm{O}_{4}: 1098.58[\mathrm{M}]^{+}, \mathrm{C}_{66}{ }^{13} \mathrm{C}_{2} \mathrm{H}_{76} \mathrm{~N}_{10} \mathrm{O}_{4}: 1099.58[\mathrm{M}]^{+}$. UV-Vis $\left(\mathrm{CH}_{2} \mathrm{Cl}_{2}\right) \lambda_{\text {max }}\left(\mathrm{A}_{\text {rel }}\right) \mathrm{nm}$ : $408(1.00), 463(0.28), 517(0.21), 542$ (0.11), $700(0.97)$. ${ }^{1} \mathrm{H}$ NMR $\left(\mathrm{CDCl}_{3}\right) \delta_{\mathrm{H}} \mathrm{ppm}: 9.65(1 \mathrm{H}, \mathrm{s}, 10-\mathrm{H})$, $9.55(1 \mathrm{H}, \mathrm{s}, 5-\mathrm{H}), 8.82(1 \mathrm{H}, \mathrm{s}, 20-\mathrm{H}), 5.42\left(1 \mathrm{H}, \mathrm{d} J=17.9 \mathrm{~Hz}, 13^{2}-\right.$ $\left.\mathrm{CH}^{2 \mathrm{a}}\right), 5.29\left(1 \mathrm{H}, \mathrm{d} J=17.9 \mathrm{~Hz}, 13^{2}-\mathrm{CH}^{2 \mathrm{~b}}\right), 4.48(1 \mathrm{H}, \mathrm{dq} J=7.4 \mathrm{~Hz}$, $J=1.7 \mathrm{~Hz}, 18-\mathrm{H}), 4.50(1 \mathrm{H}, \mathrm{m}, 17-\mathrm{H}), 4.00\left(2 \mathrm{H}, \mathrm{q} J=7.8 \mathrm{~Hz}, 3^{1}-\right.$ $\left.\mathrm{CH}_{2}\right), 3.85\left(2 \mathrm{H}, \mathrm{q} J=7.8 \mathrm{~Hz}, 8^{1}-\mathrm{CH}^{2}\right), 3.72\left(3 \mathrm{H}, \mathrm{s}, 12^{1}-\mathrm{CH}_{3}\right), 3.60$ $\left(3 \mathrm{H}, \mathrm{s}, 17^{4}-\mathrm{CH}_{3}\right), 3.45\left(3 \mathrm{H}, \mathrm{s}, 2^{1}-\mathrm{CH}_{3}\right), 3.42\left(3 \mathrm{H}, \mathrm{s}, 7^{1}-\mathrm{CH}_{3}\right), 2.79$ $\left(1 \mathrm{H}, \mathrm{m}, 17^{1}-\mathrm{CH}^{2 \mathrm{a}}\right), 2.61\left(1 \mathrm{H}, \mathrm{m}, 17^{2}-\mathrm{CH}^{2 \mathrm{a}}\right), 2.40\left(1 \mathrm{H}, \mathrm{m}, 17^{1}-\mathrm{CH}^{2 \mathrm{~b}}\right)$, $2.26\left(1 \mathrm{H}, \mathrm{m}, 17^{2}-\mathrm{CH}^{2 \mathrm{~b}}\right), 1.87\left(3 \mathrm{H}, \mathrm{d} J=7.4 \mathrm{~Hz}, 18^{1}-\mathrm{CH}_{3}\right), 1,82(3 \mathrm{H}$, t $\left.J=7.8 \mathrm{~Hz}, 3^{2}-\mathrm{CH}_{3}\right), 1.81\left(3 \mathrm{H}, \mathrm{t} J=7.8 \mathrm{~Hz}, 8^{2}-\mathrm{CH}_{3}\right), 0.18$ and -2.63 $(2 \mathrm{H}$, each bs, $\mathrm{NH} \times 2)$.

Methylpyropheophorbide a azine (5). To a solution of $100 \mathrm{mg}(0.182 \mathrm{mmol})$ of methylpyropheophorbide $a$ in 30 $\mathrm{mL}$ of $\mathrm{CH}_{2} \mathrm{Cl}_{2}$ hydrazine hydrate $(9 \mu \mathrm{L}, 0.182 \mathrm{mmol})$ and TFA $(14 \mu \mathrm{L}, 0.182 \mathrm{mmol})$ were added. The reaction was heated at 40 ${ }^{\circ} \mathrm{C}$ and the progress was monitored by TLC $(15 \mathrm{~h})$. The reaction mixture was poured to solution of $0.01 \mathrm{M} \mathrm{NaHCO}$ and extracted with $\mathrm{CH}_{2} \mathrm{Cl}_{2}$. The combined extracts were washed with water, dried over $\mathrm{Na}_{2} \mathrm{SO}_{4}$, and evaporated in vacuo to dryness. The residue was redisolved in $\mathrm{CH}_{2} \mathrm{Cl}_{2}$ and purified by preparative thin-layer chromatography in a $\mathrm{CH}_{2} \mathrm{Cl}_{2} / \mathrm{MeOH}$ system (100:1) to afford 5 (92 $\mathrm{mg}, 93 \%$ \%). $\mathrm{m} / \mathrm{z}$ (SALDI) found: 1092.3, 1093.3, 1094.2, 1095.3; calcd for $\mathrm{C}_{68} \mathrm{H}_{72} \mathrm{~N}_{10} \mathrm{O}_{4}: 1092.57[\mathrm{M}]^{+}, \mathrm{C}_{67}{ }^{13} \mathrm{CH}_{72} \mathrm{~N}_{10} \mathrm{O}_{4}: 1093.58$
$[\mathrm{M}]^{+}, \mathrm{C}_{66}{ }^{13} \mathrm{C}_{2} \mathrm{H}_{72} \mathrm{~N}_{10} \mathrm{O}_{4}: 1094.58[\mathrm{M}]^{+}, \mathrm{C}_{65}{ }^{13} \mathrm{C}_{3} \mathrm{H}_{72} \mathrm{~N}_{10} \mathrm{O}_{4}: 1095.58$ $[\mathrm{M}]^{+}$. UV-Vis $\left(\mathrm{CH}_{2} \mathrm{Cl}_{2}\right) \lambda_{\text {max }}\left(\mathrm{A}_{\text {rel }}\right) \mathrm{nm}: 406(1.00), 465(0.28), 516$ (0.19), $544(0.06), 709(0.99)$. ${ }^{\mathrm{r}} \mathrm{H} \mathrm{NMR}\left(\mathrm{CDCl}_{3}\right) \delta_{\mathrm{H}} \mathrm{ppm}: 9.68(1 \mathrm{H}$, s, 10-H), $9.62(1 \mathrm{H}, \mathrm{s}, 5-\mathrm{H}), 8.85(1 \mathrm{H}, \mathrm{s}, 20-\mathrm{H}), 8.19(1 \mathrm{H}, \mathrm{dd} J=11.4$ $\left.\mathrm{Hz}, J=17.9 \mathrm{~Hz}, 3^{1}-\mathrm{H}\right), 6.37\left(1 \mathrm{H}, \mathrm{d} J=17.9 \mathrm{~Hz}, 3^{2}-\mathrm{H}^{\mathrm{a}}\right), 6.21(1 \mathrm{H}, \mathrm{d}$ $\left.J=11.4 \mathrm{~Hz}, 3^{2}-\mathrm{H}^{\mathrm{b}}\right), 6.07\left(1 \mathrm{H}, \mathrm{d} J=18.8 \mathrm{~Hz}, 13^{2}-\mathrm{CH}^{2 \mathrm{a}}\right), 5.99(1 \mathrm{H}, \mathrm{d}$ $\left.J=18.8 \mathrm{~Hz}, 13^{2}-\mathrm{CH}^{2 \mathrm{~b}}\right), 4.70(2 \mathrm{H}, \mathrm{m}, 18-\mathrm{H}, 17-\mathrm{H}), 4.03(3 \mathrm{H}, \mathrm{s}, 12-$ $\left.\mathrm{CH}_{3}\right), 3.80\left(2 \mathrm{H}, \mathrm{q} J=7.6 \mathrm{~Hz}, 8^{1}-\mathrm{CH}_{2}\right), 3.69\left(3 \mathrm{H}, \mathrm{s}, 17^{2}-\mathrm{CO}_{2} \mathrm{CH}_{3}\right)$, $3.57\left(3 \mathrm{H}, \mathrm{s}, 2-\mathrm{CH}_{3}\right), 3.36\left(3 \mathrm{H}, \mathrm{s}, 7-\mathrm{CH}_{3}\right), 2.95\left(1 \mathrm{H}, \mathrm{m}, 17^{1}-\mathrm{CH}^{2 \mathrm{a}}\right)$, $2.67\left(1 \mathrm{H}, \mathrm{m}, 17^{2}-\mathrm{CH}^{2 \mathrm{a}}\right), 2.56\left(1 \mathrm{H}, \mathrm{m}, 17^{1}-\mathrm{CH}^{2 \mathrm{~b}}\right), 2.32\left(1 \mathrm{H}, \mathrm{m}, 17^{2}-\right.$ $\left.\mathrm{CH}^{2 \mathrm{~b}}\right), 2.02\left(3 \mathrm{H}, \mathrm{d} J=7.4 \mathrm{~Hz}, 18^{1}-\mathrm{CH}_{3}\right), 1.80\left(3 \mathrm{H}, \mathrm{t} J=7.6 \mathrm{~Hz}, 8^{2}-\right.$ $\left.\mathrm{CH}_{3}\right), 0.12$ and $-2.60(2 \mathrm{H}$, each bs, $\mathrm{NH} \times 2)$.

\section{Results and Discussion}

The search for the efficient synthetic pathways for introduction of the conjugated substituents along the $y$-axis of the chlorinmacrocycle is of great interest. Therecentfindings in hydrazone chemistry related to a palladium-catalyzed cross-coupling reaction involving a tosylhydrazone coupling partner ${ }^{[34]}$ and $\mathrm{Cu}(\mathrm{I})$-mediated olefination ${ }^{[35,36]}$ have triggered our attention towards the 13-carbonyl group modification in a pyropheophorbide $a$ series via corresponding hydrazones. Hydrazones are also known to possess anticancer activity and the combined PDT and cytostatic effect was achieved for a series of purpurinimide based hydrazones. ${ }^{[37]}$

In the present communication we describe our initial study of the reaction between methylpyropheophorbide $a$ and hydrazine (Scheme 1). It is known, that chlorophyll $a$ derivatives may provide corresponding mesocompounds upon treatment with hydrazine via reduction by diimide. ${ }^{[38]}$ It was also shown, that the hydrogenation of the 3-vinyl group may be suppressed by carrying out the reaction under air-free conditions. ${ }^{[37]}$ Additionally, unsubstituted hydrazones bearing terminal $\mathrm{NH}_{2}$ group are oxidized in the air or by other oxidizing agents yielding azines, what may complicate handling and purification. ${ }^{[39,40]}$ In order to prevent azine formation a 10 -fold excess of hydrazine hydrate was applied for the reaction with pyropheophorbide a methyl ester (1). Under these conditions, the 3-vinyl group was completely hydrogenated and hydrazone of methylmesopyropheophorbide (2) was isolated as a single product in $76 \%$ yield. Decrease of the hydrazine hydrate excess gave rise to the bathochromic shift in the absorption spectrum (701 nm, Figure 1) of the reaction mixture due to formation of hydrogenated azine 4, culminating in $90 \%$ yield of $\mathbf{4}$ when equimolar amounts of the reagents were subjected to the reaction.

On the other hand, presence of the unsaturated $C 3$-substituent may be important for the creation of chlorophyll $a$ derivatives with particular optical properties and C3and $C 13$-bifunctionalized chlorins. Addition of TFA prevented the hydrogenation process and hydrazone $\mathbf{3}$ and azine $\mathbf{5}$ of methylpyropheophorbide $a$ were formed in the presence of acid. ${ }^{[41]}$ The amount of TFA was found to be an important factor influencing the outcome of the reaction. The selective azine 5 formation (93\% yield) was achieved by applying 1 eq. of hydrazine hydrate along with 1 eq. of TFA, accompanied by a characteristic change in absorption spectrum where the $Q_{y}$ maximum was red-shifted to $709 \mathrm{~nm}$ (Figure 1). Further reaction condition optimization allowed us to find the hydrazine hydrate/TFA $(2: 1)$ ratio, which 

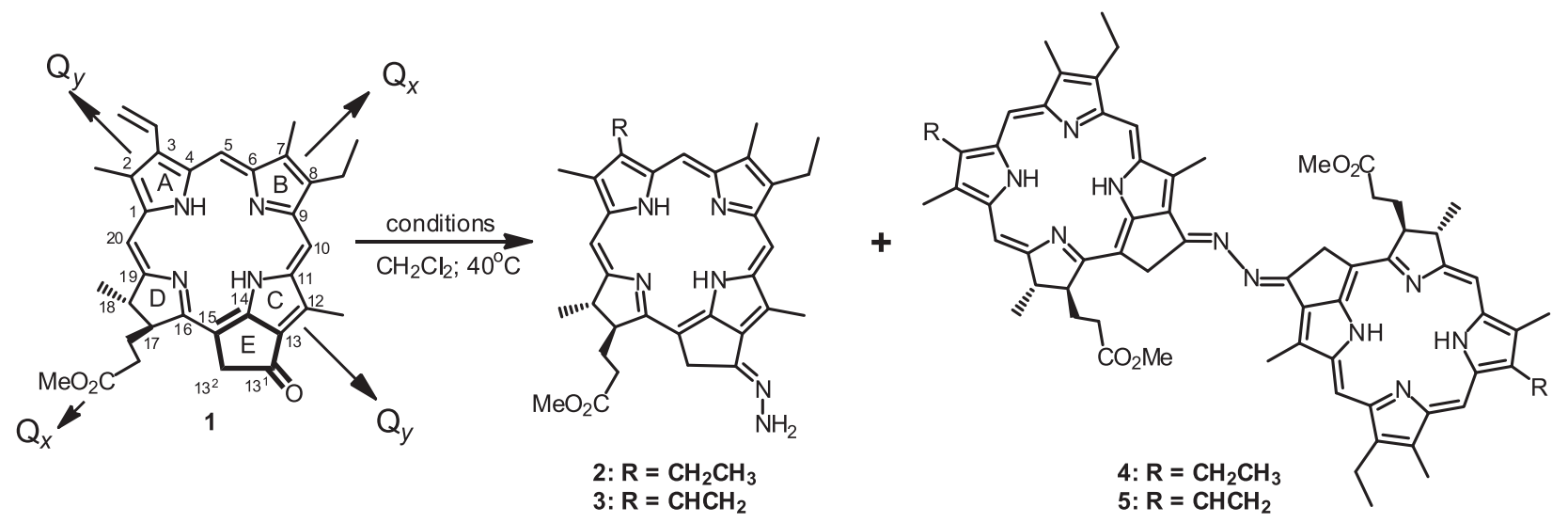

\begin{tabular}{|c|c|c|c|c|c|c|}
\hline \multicolumn{2}{|c|}{ Reagents, (eq.) } & \multirow{2}{*}{$\begin{array}{l}\text { Reaction } \\
\text { time }\end{array}$} & \multicolumn{4}{|c|}{ Product yields, \% } \\
\hline $\mathrm{N}_{2} \mathrm{H}_{4} \times 2 \mathrm{H}_{2} \mathrm{O}$ & TFA & & 2 & 3 & 4 & 5 \\
\hline 1 & - & 3 days & 5 & - & 90 & - \\
\hline 3 & - & 3 days & 40 & - & 50 & - \\
\hline 10 & - & 3 days & 76 & - & - & - \\
\hline 1 & 1 & $15 \mathrm{~h}$ & - & 5 & - & 93 \\
\hline 3 & 1 & $15 \mathrm{~h}$ & 29 & 68 & - & - \\
\hline 10 & 1 & $15 \mathrm{~h}$ & 42 & 47 & - & - \\
\hline 7 & 5 & $15 \mathrm{~h}$ & 11 & 45 & - & - \\
\hline 3 & 5 & $15 \mathrm{~h}$ & - & 30 & - & 25 \\
\hline 2 & 1 & $15 \mathrm{~h}$ & 12 & 65 & - & $<5$ \\
\hline
\end{tabular}

Scheme 1. Reaction of methylpyropheophorbide $a$ and hydrazine. The details of the reaction conditions and product yields are listed in the table.

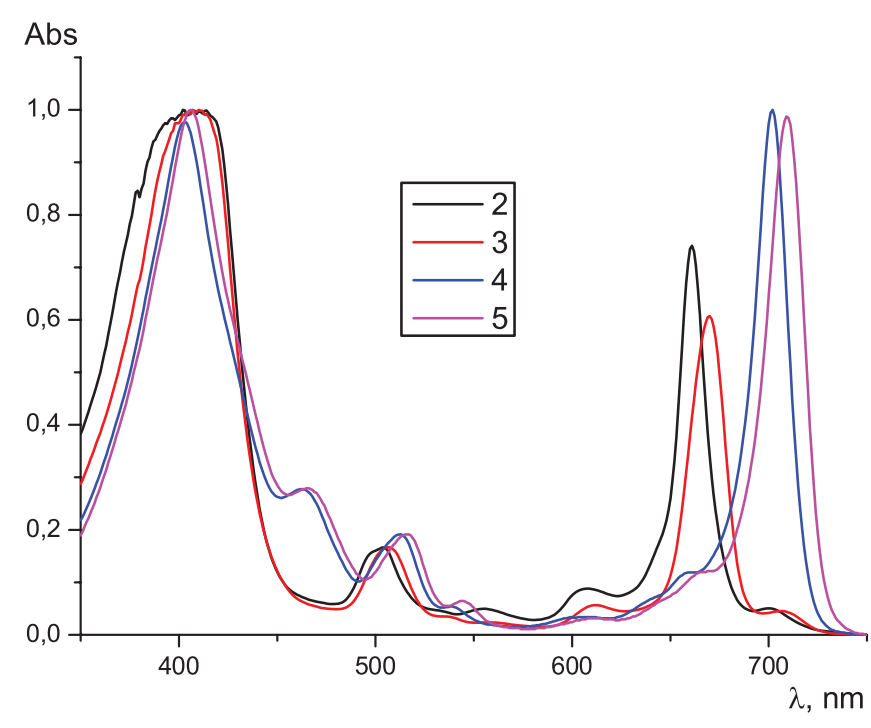

\begin{tabular}{cccccc}
\hline \multirow{2}{*}{ Compound } & \multicolumn{5}{c}{$\lambda_{\text {abs }}, \mathrm{nm}$} \\
\cline { 2 - 6 } & Soret & $Q_{x}(0,1)$ & $Q_{x}(0,0)$ & $Q_{y}(0,1)$ & $Q_{y}(0,0)$ \\
\hline $\mathbf{2}$ & 403 & 504 & 555 & 608 & 661 \\
$\mathbf{3}$ & 407 & 506 & 534 & 612 & 670 \\
$\mathbf{4}$ & 408 & 463 & 517 & 542 & 700 \\
$\mathbf{5}$ & 406 & 465 & 516 & 544 & 709
\end{tabular}

Figure 1. Comparison of the electronic absorption spectra of compounds $\mathbf{2}-\mathbf{5}$. provided hydrazone 3 formation with reasonable selectivity (Scheme 1).

The obtained compounds have been characterized by electronic absorption spectra, and their structures have been confirmed using mass-spectrometry and NMR spectroscopy.

\section{Crystal structure}

The formation of the dimeric azine structure was also determined by the X-ray powder diffraction using a high crystallinity powder sample of $\mathbf{5}$. In the crystal, the title molecule $\mathbf{5}$ possesses by a crystallographically imposed rotational symmetry, with the two-fold axis passing through the middle of N5-N5a bond (see Figure 2; prepared with PLATON) $\cdot{ }^{[42]}$ All bond lengths and angles in the molecule are normal and comparable with those observed in the Cambridge Structural Database ${ }^{[43]}$ for related compounds. Two mean planes formed by four $\mathrm{N}$ atoms from each macrocycle are inclined to each other at $13.4(9)^{\circ}$. Two chlorin macrocycles in the molecule are arranged in such a way, that propionic ester residues are situated at the same side of the molecule plane. Pyrrolic NH are involved in intramolecular $\mathrm{N}-\mathrm{H}$...H hydrogen bonds (Table 2). In the absence of classical intermolecular hydrogen bonds, the crystal packing (Figure 3; prepared with Mercury $)^{[44]}$ is stabilized by the weak $\mathrm{C}-\mathrm{H}$...O hydrogen bonds (Table 2) and Van der Waals interactions. 


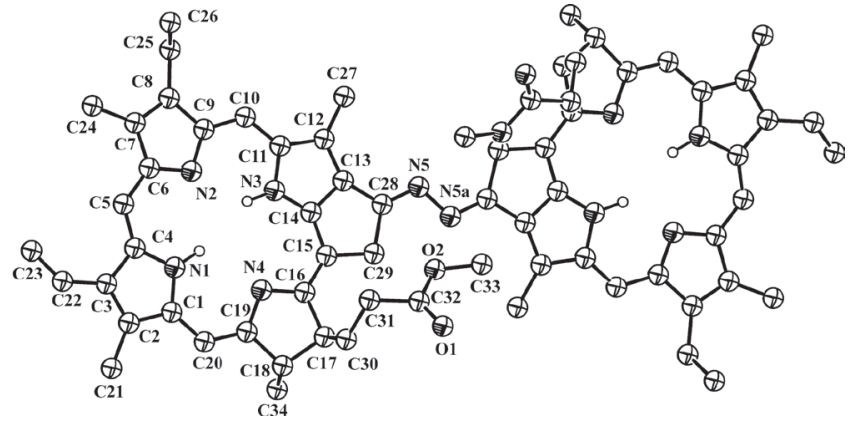

Figure 2. The molecular structure of $\mathbf{5}$ showing the atomic numbering and $50 \%$ probability displacement spheres. Unlabelled atoms are related to labeled ones via symmetry operation (a) $-x, y$, $-z$. C-bound $\mathrm{H}$ atoms are omitted for clarity.

\section{Conclusions}

The interaction between pyropheophorbide $a$ methyl ester (1) and hydrazine hydrate has been studied under different reaction conditions. It was shown, that the reaction outcome is influenced by the hydrazine excess and TFA amount. The presence of acid is essential for preserving the 3-vinyl group of pyropheophorbide $a$ from reduction by diimide. The collected experimental data allowed us to propose the specific reaction conditions for selective formation of each out of possible products, what was confirmed by the targeted synthesis of compounds $\mathbf{2 - 5}$.

This preliminary study gave us valuable insights for further employment of pyropheophorbide hydrazones that will be useful for introduction of conjugated substituents
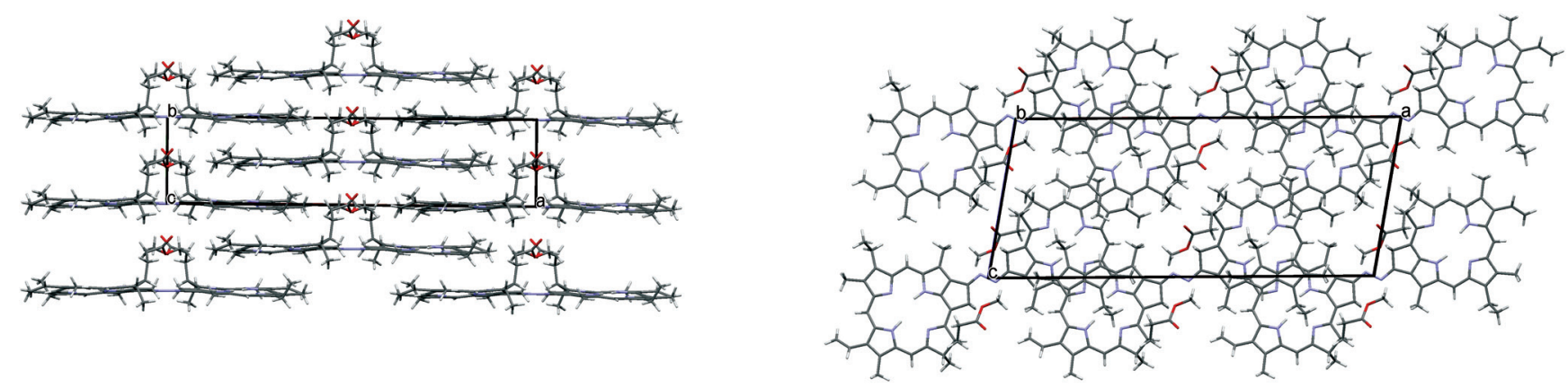

Figure 3. A portion of the crystal packing of 5 viewed in two orthogonal directions: in [001] (left) and [010] (right).

Table 1. Crystallographic data for 5 .

\begin{tabular}{cc}
\hline & $\mathbf{5}$ \\
\hline Empirical formula & $\mathrm{C}_{68} \mathrm{H}_{72} \mathrm{~N}_{10} \mathrm{O}_{4}$ \\
Formula weight & 1093.36 \\
Crystal system & monoclinic \\
Space group & $C 2$ \\
$a, \AA$ & $30.9590(17)$ \\
$b, \AA$ & $7.1638(8)$ \\
$c, \AA$ & $12.9242(11)$ \\
$a$, deg & 90 \\
$b$, deg & $100.099(18)$ \\
$g$, deg & 90 \\
$V, \AA^{3}$ & $2822.0(4)$ \\
$Z$ & 2 \\
$R_{p} / R_{w p} / R_{\text {exp }}$ & $0.0283 / 0.03748 / 0.0196$ \\
$\chi^{2}$ & 1.904 \\
\hline
\end{tabular}

Table 2. Hydrogen-bonding geometry $\left(\AA,^{\circ}\right)$ in $\mathbf{5}$.

\begin{tabular}{|c|c|c|c|c|}
\hline D-H...A & $\mathrm{D}-\mathrm{H}$ & H...A & D...A & D-H...A \\
\hline $\mathrm{N} 1-\mathrm{H} 1 \ldots \mathrm{N} 2$ & $0.98(6)$ & $2.47(7)$ & $3.050(11)$ & $118(4)$ \\
\hline N1-H1 ...N4 & $0.98(6)$ & $2.32(6)$ & $2.907(11)$ & $118(5)$ \\
\hline $\mathrm{N} 3-\mathrm{H} 3 \ldots \mathrm{N} 2$ & $0.97(6)$ & $1.98(6)$ & $2.713(9)$ & $131(6)$ \\
\hline С29-H29B...O2 & 0.97 & 2.13 & $3.074(17)$ & 162 \\
\hline C34-H34A...O $1^{\mathrm{i}}$ & 0.96 & 2.40 & $2.833(14)$ & 107 \\
\hline
\end{tabular}

Symmetry code: (i) $-\mathrm{x},-1+\mathrm{y}, 1-\mathrm{z}$. along the $y$-axis of the macrocycle to form $\pi$-extended chlorin systems with tuneable optical properties.

Acknowledgements. This research was supported by the Russian Ministry of Science and Education, grant No. RFMEFI61616X0069. We also thank ESRF for the access to ID22 station, experiment MA-3313.

Supporting Information. X-ray Crystallographic file in CIF format. Crystallographic data for $\mathbf{5}$ have been deposited with the Cambridge Crystallographic Data Centre as the supplementary publication nos. CCDC 1533815. Copies of data can be obtained free of charge on application to CCDC, 12 Union Road, Cambridge CB21EZ, UK (fax: (44)1223-336-033; e-mail: deposit@ccdc.cam.ac.uk).

\section{References}

1. Wang X.-F., Kitao O. Molecules 2012, 17, 4484-4497.

2. Yoon I., Li J.Z., Shim Y.K. Clinical Endoscopy 2013, 46, 7-23.

3. Borisov S.M., Papkovsky D.B., Ponomarev G.V., DeToma A.S., Saf R., Klimant I. J. Photochem. Photobiol. A: Chem. 2009, 206, 87-92.

4. Zhuang T., Sasaki S., Ikeuchi T., Kido J., Wang X.-F. RSC Adv. 2015, 5, 45755-45759.

5. Tamiaki H., Tanaka T., Wang X.-F. J. Photochem. Photobiol. A: Chem. 2015, 313, 19-26.

6. Wang X.-F., Tamiaki H., Kitao O., Ikeuchi T., Sasaki S. J. Power Sources 2013, 242, 860-864. 
7. Hug H., Bader M., Mair P., Glatzel T. Applied Energy 2014, $115,216-225$.

8. Li Y., Li H., Song P., Sun C. J. Nanomater. 2015, 1-6.

9. Yamamoto Y., Tamiaki H. Dyes Pigm. 2015, 118, 159-165.

10. Okamoto Y., Tamiaki H. J. Photochem. Photobiol. A: Chem. 2011, 219, 250-254.

11. Liu M., Chen C.-Y., Mandal A.K., Chandrashaker V., EvansStorms R.B., Pitner J.B., Bocian D.F., Holten D., Lindsey J.S. New J. Chem. 2016, 40, 7721-7740.

12. Sasaki S., Mizutani K., Kunieda M., Tamiaki H. Tetrahedron 2011, 67, 6065-6072.

13. Kinoshita Y., Kunieda M., Mikata Y., Tamiaki H. Tetrahedron Lett. 2013, 54, 1243-1246.

14. Sasaki S., Mizutani K., Kunieda M., Azuma K., Tamiaki H. Chem. Lett. 2013, 42, 1212-1213.

15. Nikkonen T., Oliva M.M., Taubert S., Melchionna M., Kahnt A., Helaja J. Chem. Eur. J. 2015, 21, 12755-12768.

16. Tamiaki H., Kuno M., Kunieda M. Tetrahedron Lett. 2014, 55, 2825-2828.

17. Tamiaki H., Koizumi S., Tsuji K., Kinoshita Y., Miyatake T. Tetrahedron Lett. 2014, 55, 1093-1096.

18. Wang J.-J., Han G.-F., Shim Y.K. J. Photoscie. 2001, 8(1), 23-25.

19. Lonin I.S., Kuzovlev A.S., Belyaev E.S., Ponomarev G.V., Oskar I.K., Tsivadze A.Yu. J. Porphyrins Phthalocyanines 2014, 18, 123-128.

20. Kenner G.W., McCombie S.W., Smith K.M. J. Chem. Soc. Perkin I, 1973, 2517-2523.

21. Gottlieb H.E., Kotlyar V., Nudelman A. J. Org. Chem. 1997, 62, 7512-7515.

22. Werner P.-E., Eriksson L., Westdahl M. J. Appl. Crystallogr. 1985, 18, 367-370.

23. Visser J.W. J. Appl. Crystallogr. 1969, 2, 89-95.

24. Zlokazov V.B. J. Appl. Crystallogr. 1992, 25, 69-72.

25. Zlokazov V.B. Comput. Phys. Commun. 1995, 85, 415-422.
26. Pawley G.S. J. Appl. Crystallogr. 1981, 14, 357-361.

27. Zhukov S.G., Chernyshev V.V., Babaev E.V., Sonneveld E.J., Schenk H. Z. Kristallogr. 2001, 216, 5-9.

28. Zlokazov V.B., Chernyshev V.V. J. Appl. Crystallogr. 1992, 25 , 447-451.

29. Laikov D.N. Chem. Phys. Lett. 1997, 281, 151-154.

30. Laikov D.N. Priroda Code, Version 5. 2004. Moscow State University.

31. Laikov D.N. Chem. Phys. Lett. 2005, 416, 116-120.

32. Laikov D.N., Ustynyuk Y.A. Russ. Chem. Bull. 2005, 54, 820826.

33. Perdew J.P.S., Burke S., Ernzerhof M. Phys. Rev. Lett. 1996, 77, 3865-3868.

34. Barluenga J., Vald C. Angew. Chem. Int. Ed. 2011, 50, 74867500 .

35. Korotchenko V.N., Shastin A.V., Nenajdenko V.G., Balenkova E.S. J. Chem. Soc., Perkin Trans. 2002, 1, 883-887.

36. Korotchenko V.N., Nenajdenko V.G., Shastin A.V., Balenkova E.S. Org. Biomol. Chem. 2003, 1, 1906-1908.

37. Li J.Z., Li L., Kim J.H., Cui B.C., Wang J.J., Shim Y.K. J. Porphyrins Phthalocyanines 2011, 15, 264-270.

38. Mironov A.F., Grin M.A., Nochovny S.A., Toukach P.V. Mendeleev Commun. 2003, 13(4), 156-157.

39. Kolb V.M., Kuffel A.C., Spiwek H.O., Janota T.E. J. Org. Chem. 1989, 54, 2771-2775.

40. Furrow M.E., Myers A.G. J. Am. Chem. Soc. 2004, 126, 54365445.

41. Miller C.E. J. Chem. Educ. 1965, 42, 254-259.

42. Spek A.L. Acta Crystallogr. D 2009, D65, 148-155.

43. Groom C.R., Allen F.H. Angew. Chem. Int. Ed. 2014, 53, 662671.

44. Macrae C.F., Bruno I.J., Chisholm J.A., Edgington P.R., McCabe P., Pidcock E., Rodriguez-Monge L., Taylor R., van de Streek J., Wood P.A. J. Appl. Crystallogr. 2008, 41, 466470 . 